\title{
Brain neuroimaging of domestic cats: correlation between computed tomography and cross- sectional anatomy
}

\author{
[Neuroimagem cerebral de gatos domésticos: correlação entre a tomografia \\ computadorizada e a anatomia seccional] \\ A.C. Nepomuceno ${ }^{1}$, R. Zanatta ${ }^{2}$, D.G. Chung ${ }^{3}$, P.F. Costa ${ }^{3}$, M.A.R. Feliciano ${ }^{3}$, M.L. Avante ${ }^{3}$, \\ L.S. Lopes ${ }^{4}$, J.C. Canola ${ }^{3}$ \\ ${ }^{1}$ Universidade Federal de Minas Gerais - UFMG - Belo Horizonte, MG \\ ${ }^{2}$ Universidade de Cuiabá - Cuiabá, MT \\ ${ }^{3}$ Faculdade de Ciências Agrárias e Veterinárias - Unesp - Jaboticabal, SP \\ ${ }^{4}$ Universidade de São Paulo - USP - Ribeirão Preto, SP
}

\begin{abstract}
Computed tomography of the brain is necessary as part of the diagnosis of lesions of the central nervous system. In this study we used six domestic cats, male or female, aged between one and five years, evaluated by Computed Tomography (CT) examination without clinical signs of central nervous system disorders. Two euthanized animals stating a condition unrelated to the nervous system were incorporated into this study. The proposal consisted in establishing detailed anatomical description of tomographic images of normal brain of cats, using as reference anatomical images of cross sections of the stained brain and cranial part, with thicknesses similar to the planes of the CT images. CT examinations were performed with and without intravenous iodinated contrast media for live animals. With one euthanized animal, the brain was removed and immediately preserved in $10 \%$ formalin for later achievement in cross-sectional thickness of approximately $4 \mathrm{~mm}$ and staining technique of Barnard, and Robert Brown. The head of another animal was disarticulated in the Atlanto-occipital region and frozen at $-20^{\circ} \mathrm{C}$ then sliced to a thickness of about $5 \mathrm{~mm}$. The description of visualized anatomical structures using tomography is useful as a guide and allows transcribing with relative accuracy the brain region affected by an injury, and thus correlating it with the clinical symptoms of the patient, providing additional information and consequent improvement to veterinarians during the course of surgical clinic in this species.
\end{abstract}

Keywords: feline, tomography, brain anatomy

\section{RESUMO}

A tomografia computadorizada do cérebro é de suma importância como parte do diagnóstico de lesões do sistema nervoso central. Neste estudo, foram utilizados seis felinos domésticos, machos ou fêmeas, com idade entre um e cinco anos, avaliados pela tomografia computadorizada (TC), sem sinais clínicos de distúrbios do sistema nervoso central. Dois cadáveres indicando a condição relacionada com o sistema nervoso foram incorporados ao presente estudo. A proposta consistiu na criação da descrição anatômica detalhada das imagens tomográficas de cérebro normal de gatos, usando como referência a imagens anatômicas de secções transversais do cérebro coradas, realizadas com espessuras similares aos planos das imagens tomográficas. Exames de TC foram realizados com e sem contraste iodado intravenoso para os animais vivos. Em um dos cadáveres, o cérebro foi removido e imediatamente preservado em formalina a $10 \%$ para a realização posterior da técnica de coloração de Barnard e Robert Brown, além de cortes transversais com espessura de, aproximadamente, $4 \mathrm{~mm}$. O crânio do outro cadáver foi desarticulado na região atlanto-occipital e congelado a $-20^{\circ} \mathrm{C}$. Em seguida, foi realizado corte com espessura de cerca de $5 \mathrm{~mm}$. A descrição das estruturas anatômicas visualizadas foi útil e serve como guia, permitindo descrever com relativa precisão a estrutura cerebral normal ou lesionada, e, portanto, correlacionando-a com os sintomas clínicos de um paciente, o que fornece informações adicionais e consequente aprimoramento de veterinários no curso de clínica cirúrgica para essa espécie.

Palavras-chave: felino, tomografia, anatomia cerebral

Recebido em 12 de dezembro de 2015

Aceito em 4 de março de 2016

*Autor para correspondência (corresponding author)

E-mail: marcusfeliciano@yahoo.com.br 


\section{INTRODUCTION}

Computed tomography (CT) of the brain of cats is a valuable tool for the diagnosis of central nervous system injuries. The first description of the use of CT in veterinary patients occurred during the 1980s, according to Ohlerth and Scharf (2007).

This diagnostic modality is based on the use of $\mathrm{x}$-rays, which can create slices of anatomical structures of the patient's body, forming transverse sections or three-dimensional images by volumetric reconstruction (Bertolini and Prokop, 2011). Basically, a CT scanner is formed by a gantry, in which there are x-ray beams and detectors on opposite sides, around a table where the patient is positioned, and a workstation, which is the computerized control center where image data is processed (Bertolini and Prokop, 2011).

Knowledge of domestic cats' brain anatomy is essential for the evaluation of images obtained by $\mathrm{CT}$, since normal brain standards are necessary for the recognition of abnormalities (Stickle and Hathcock, 1993). According to Jones (2004), publications and anatomy texts are vital for the understanding of CT images.

Although imaging techniques have been improving in the past years, and scientific reports on the use of computed tomography for brain lesions in domestic cats are available, publications serving as a reference guide for the normal brain are scarce (Lecouteur et al., 1983; Lecouteur, 1999; Kawasaki et al., 2003; Adamo, 2005; Forterre et al., 2006; Goulle et al., 2011; Gutierrez-Quintana et al., 2011; Thomas, 1999). Therefore, this study aimed to describe the anatomy structures visualized on CT images, correlating them with anatomical sections of the brain, to serve as a guide for veterinarians. This will allow for a fairly precise identification of brain lesions, allowing correlation to the patient's clinical signs, providing additional information, and enhancing the practice of feline medicine in this species.

\section{MATERIAL AND METHODS}

Eight mongrel domestic cats, of both sexes, with ages between one and five years, were used in this study. Six of them were presented to the
Veterinary Hospital at São Paulo State University, UNESP, Jaboticabal, Brazil, for computed tomography scans, with no clinical signs of central nervous system disorders. Two cats attended at private veterinary practices and with indication of euthanasia due to medical reasons not related to neurological disease were included in the study.

This study was conducted following the Ethical Principles for Animal Experimentation adopted by the Brazilian College of Animal Experimentation (COBEA) and approved by the Ethics Committee on Animal Use (CEUA) of the School of Agricultural and Veterinary Sciences UNESP, Jaboticabal, SP, Brazil under protocol no. $022590 / 12$.

Parameters such as weight, rectal temperature, cardiac and pulmonary auscultation, and abdominal palpation were evaluated on clinical examination.

Each patient was evaluated to determine general health condition. To participate in the study and before the anesthetic procedures, patients received cardiac and neurological evaluations. None of the animals exhibited alterations on these evaluations.

After clinical examination and a 12 hour fast, animals were subjected to intramuscular (IM) pretreatment with chlorpromazine hydrochloride at $0.5 \mathrm{mg} / \mathrm{kg}$ (Amplictil $25 \mathrm{mg}$ - Aventis Pharma LTDA - São Paulo), and dissociative anesthesia with tiletamine hydrochloride and zolazepam hydrochloride at $0.4 \mathrm{mg} / \mathrm{kg}$ (IM) (Zoletil $50 \mathrm{mg} / \mathrm{Kg}$ - Virbac do Brasil Indístria e Comércio LTDA - São Paulo).

The cephalic vein of all animals remained cannulated with a sterile infusion circuit and sodium chloride solution to insure access in case of emergency, anesthesia maintenance, and administration of contrast solution.

Computed tomography exams were performed at the Veterinary Hospital of São Paulo State University, UNESP/ Jaboticabal/SP, Diagnostic Imaging Section, with a third generation axial CT scanner (GE Healthcare, CT Max 640).

The CT images were obtained with animals in sternal recumbency, with thoracic limbs 
extended caudally to avoid artifacts, and pelvic limbs positioned cranially.

For the brain scan, a window level (WL) of 50 Hounsfield units (HU) and a window width (WW) of 300HU were used, in accordance with Tidwell (2007). A sagittal image of the head, also called scout view or topogram, of each animal was performed to define the beginning and end of the brain scan. Next, the equipment was adjusted for an electric current of $22 \mathrm{~mA}$ (extra low), voltage of $120 \mathrm{kVp}$, time of $4.8 \mathrm{~s}$, and slice thickness of $5 \mathrm{~mm}$, starting the scan at the cribriform plate of the ethmoid bone and finishing at the cranial atlas, in agreement with Lecouteur et al. (1983). Following acquisition of tomographic images, a second series of images was repeated after intravenous administration of non-toxic iodinated contrast (Iohexol Omnipaque 300mg I/mL GE Healthcare) via the cephalic vein at a dose of $1 \mathrm{mg} / \mathrm{kg}$ of body weight, to exclude the presence of lesions, as recommended by Fike et al. (1986).

To perform the anatomical sections, two animals attended at private veterinary clinics and with indication of euthanasia due to disease unrelated to the nervous system were included in the study.

After euthanasia, one of the animals had the head disarticulated at the atlanto-occipital joint. Immediately after, the skin, temporal muscles, skull, dura mater, and membranous tentorium were removed. The brain was removed and immediately immersed in a $10 \%$ formaldehyde solution. At the Experimental Surgery Section of the Medicine School at University of São Paulo (USP) - Ribeirão Preto campus, the brain was sectioned into $4 \mathrm{~mm}$ transverse planes in a specific cast (Cat Brain Matrix, ASI Instruments 2mm, Warren Michigan, USA) for cat brain, and stained using the "Barnard, Robert, and Brown" technique (Meneses et al., 2004), which stains the gray matter in blue allowing for distinction between both nervous tissue types.

On the first step, sections were immersed for approximately two minutes in "Mulligan" solution (phenol 4g, hydrochloridic acid $0.125 \mathrm{~mL}$, copper sulfate $0.5 \mathrm{~g}$, and water $100 \mathrm{~mL}$ ) previously heated to $60-650 \mathrm{C}$ in a water bath, then rinsed in warm running water for one minute. On the second step, sections were placed in $1 \%$ ferric chloride for three minutes and washed in running water for one minute. On the third step, sections were immersed in a $1 \%$ potassium ferricyanide for one minute, and then washed in running water for one minute. Subsequently, sections were submerged in a fixative solution of $10 \%$ formaldehyde acidified with hydrochloric acid obtaining a $2 \%$ final solution.

At the Veterinary Pathology Department of the School of Agricultural and Veterinary Sciences, UNESP, Jaboticabal, SP, Brazil, the second brain was processed as follows: After euthanasia, the head was disarticulated at the atlanto-occipital joint and frozen at $-20 \mathrm{oC}$, and was then sectioned transversally into $5 \mathrm{~mm}$ slices using a bandsaw.

The rostral surface of each anatomical section was identified, photographed, and compared to the CT images.

To analyze the results, each anatomical section of the head and of the stained brain were photographed and paired to the corresponding image obtained by computed tomography. Identification of structures on anatomical sections was based on literature.

\section{RESULTS}

New drug administration was not necessary during anesthesia. No lesions were seen on the domestic cats' post-contrast computed tomography images.

The ten stained transverse anatomical sections of the brain of one cat were photographed at their rostral surface.

The identification of the brain structures as well as the comparison between the stained anatomical sections, sections of the head and transverse CT images are all presented following a rostrocaudal direction of the brain (Fig. 1, 2, 3, 4, 5, 6, 7, 8, and 9): 1. Cerebral hemisphere 2 . Frontal lobe 3 . Olfactory bulb 4. Frontal sinus 5 . Jaw 6. Nasopharynx 7. Oropharynx 8. Gray matter 9. White matter 10 . Olfactory tract 11. Longitudinal fissure 12. Caudate nucleus 13. Fornix 14. Corpus callosum 15. Lateral ventricule 16. Internal capsule 17. Rostral commissure 18. Parietal lobe 19. Hippocampus 20. Thalamus 21. Internal capsule 22. Cerebral peduncule 23 . Third ventricle 24 . Temporal lobe 
25. Piriform lobe 26. Mesencephalon 27. Fimbria 28. Mesencephalic aqueduct 29. Periaquedutal gray matter 30 . Tympanic bulla 31 . Pons 32 . Cistern of colliculus 33. Colliculus 34. Interpeduncular cistern 35. External ear canal 36.
Occipital lobe 37. Vermis of cerebellum 38. White matter cerebellar 39. Fouth ventricle 40. Bulbar pyramid 41. Cerebellar hemisphere 42 . Brainstem 43. Cerebellum.
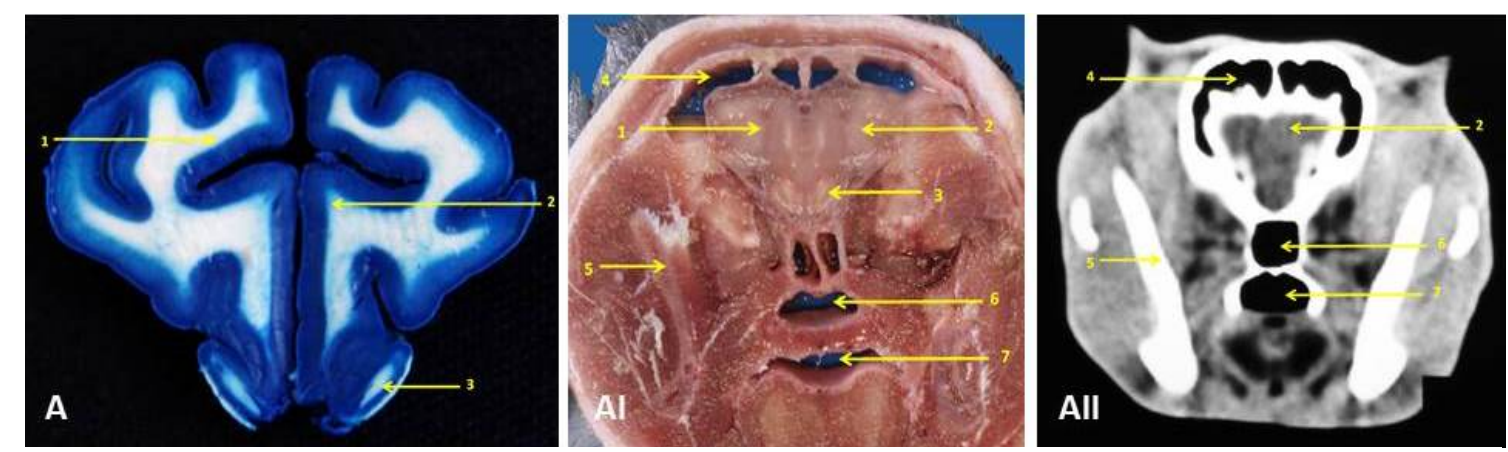

Figure 1. Images corresponding to transverse sections of the cat's brain with identification of anatomical structures. A: Section of brain stained using the Barnard, Robert, and Brown technique. AI: Anatomical section of the head. AII: Computed tomography section.
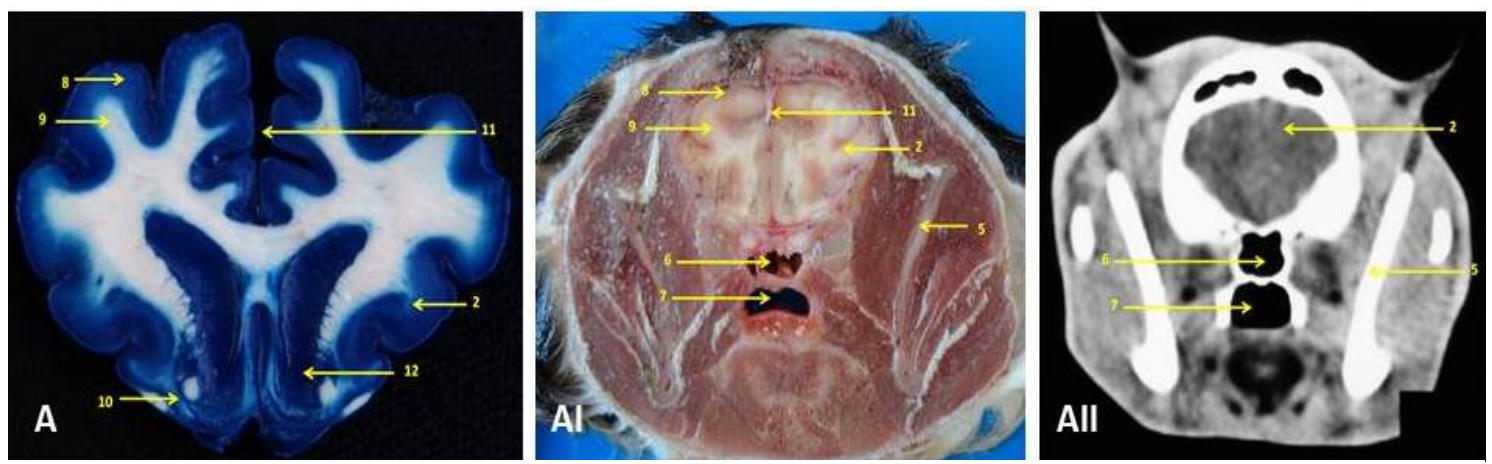

Figure 2. Images corresponding to transverse sections of the cat's brain with identification of anatomical structures. A: Section of brain stained using the Barnard, Robert, and Brown technique. AI: Anatomical section of the head. AII: Computed tomography section.
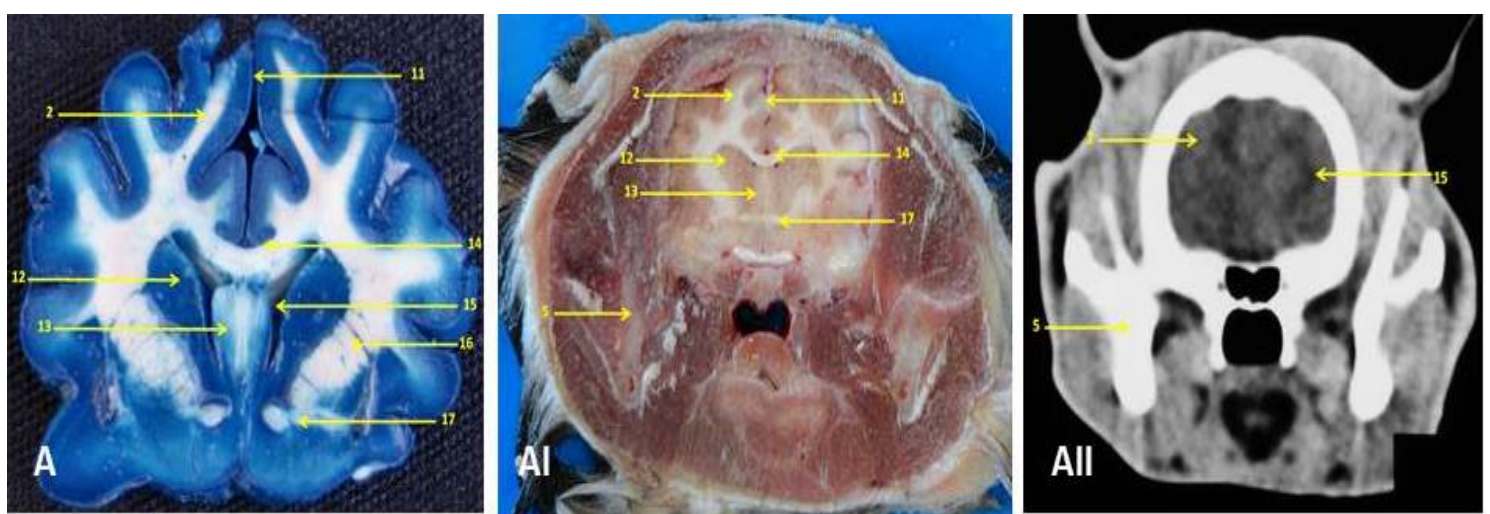

Figure 3. Images corresponding to transverse sections of the cat's brain with identification of anatomical structures. A: Section of brain stained using the Barnard, Robert, and Brown technique. AI: Anatomical section of the head. AII: Computed tomography section. 

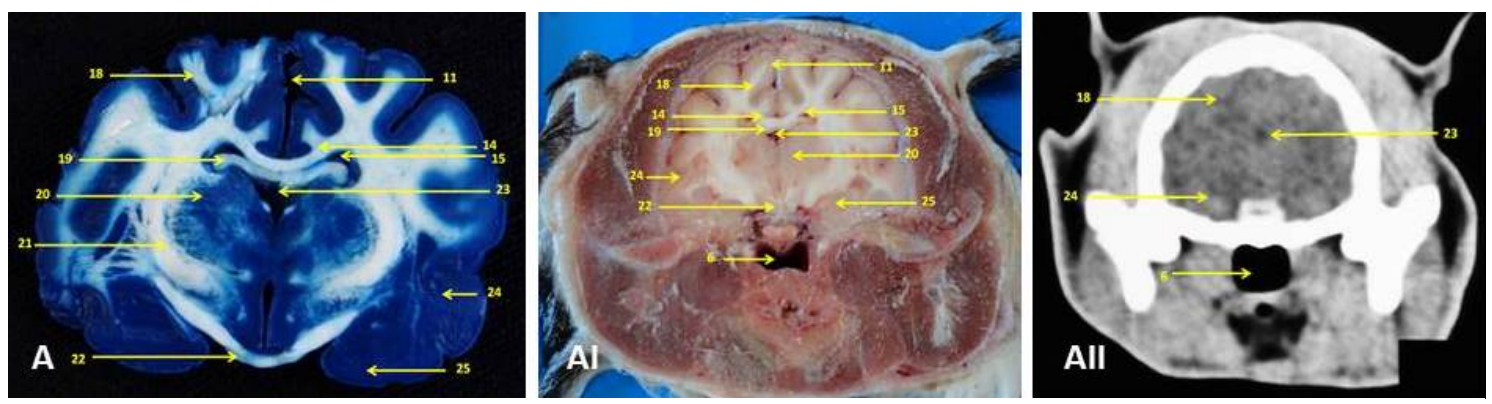

Figure 4. Images corresponding to transverse sections of the cat's brain with identification of anatomical structures. A: Section of brain stained using the Barnard, Robert, and Brown technique. AI: Anatomical section of the head. AII: Computed tomography section.
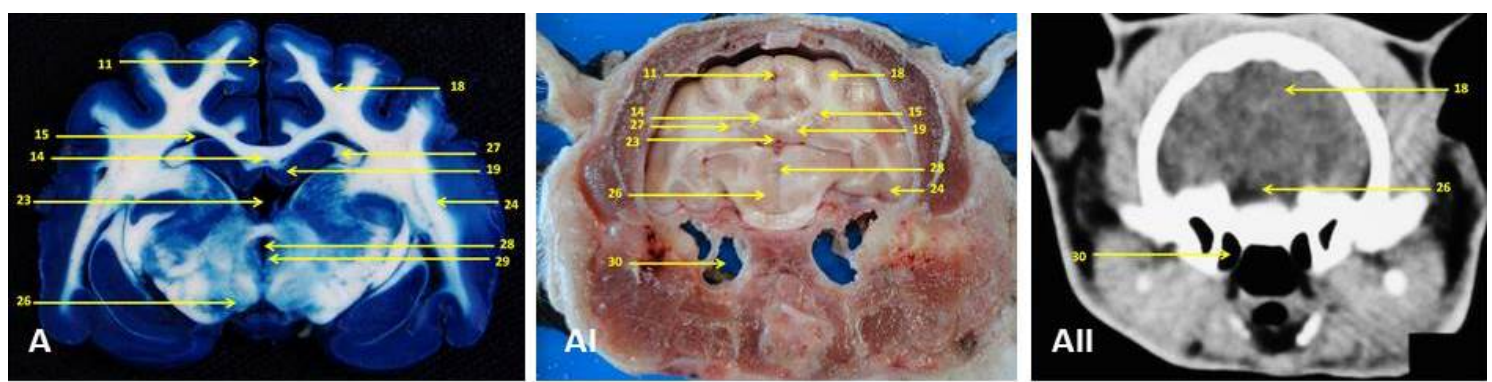

Figure 5. Images corresponding to transverse sections of the cat's brain with identification of anatomical structures. A: Section of brain stained using the Barnard, Robert, and Brown technique. AI: Anatomical section of the head. AII: Computed tomography section.
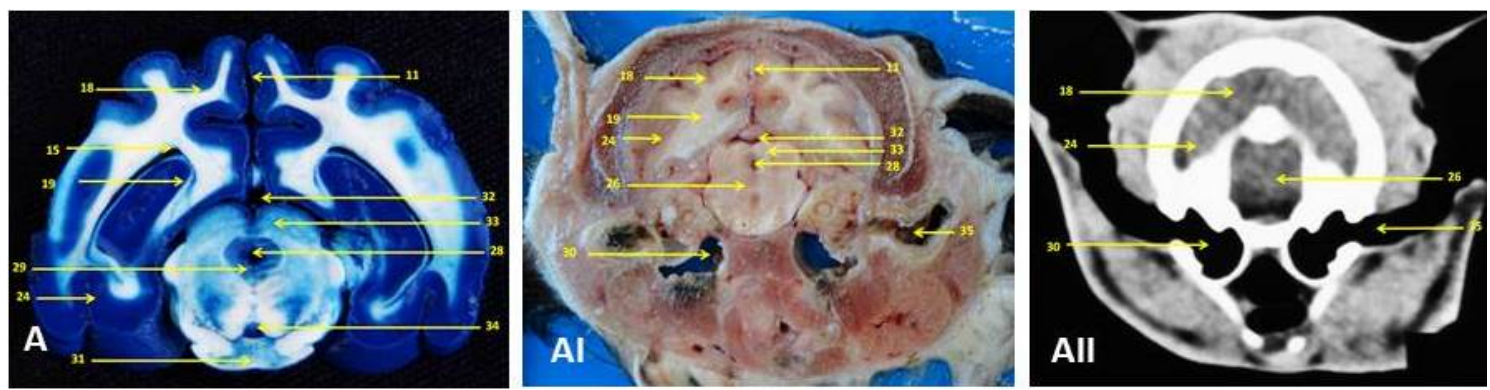

Figure 6. Images corresponding to transverse sections of the cat's brain with identification of anatomical structures. A: Section of brain stained using the Barnard, Robert, and Brown technique. AI: Anatomical section of the head. AII: Computed tomography section.
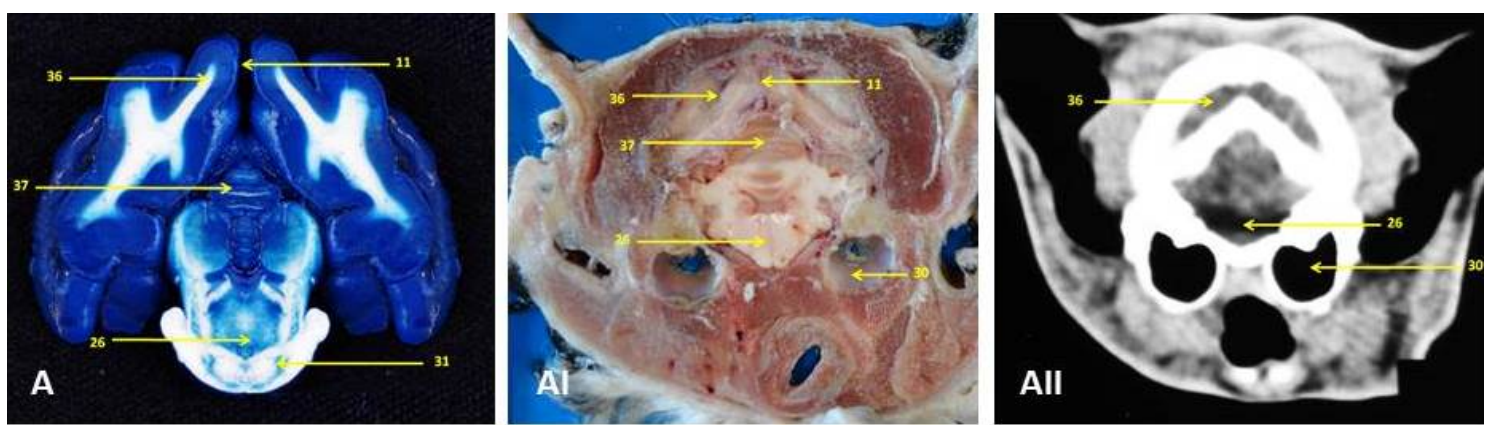

Figure 7. Images corresponding to transverse sections of the cat's brain with identification of anatomical structures. A: Section of brain stained using the Barnard, Robert, and Brown technique. AI: Anatomical section of the head. AII: Computed tomography section. 

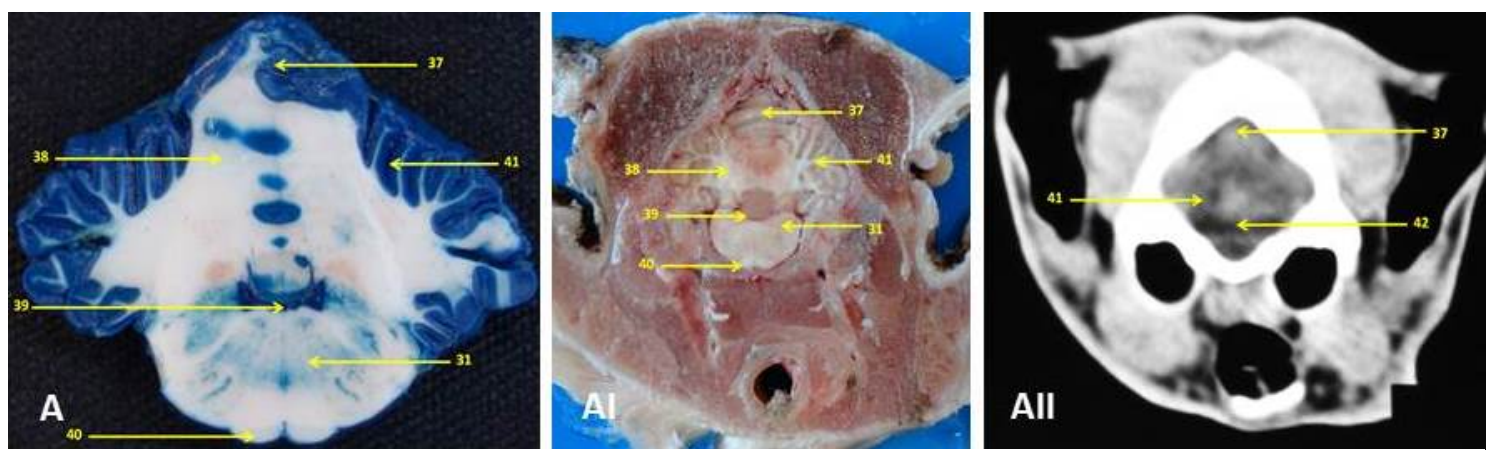

Figure 8. Images corresponding to transverse sections of the cat's brain with identification of anatomical structures. A: Section of brain stained using the Barnard, Robert, and Brown technique. AI: Anatomical section of the head. AII: Computed tomography section.
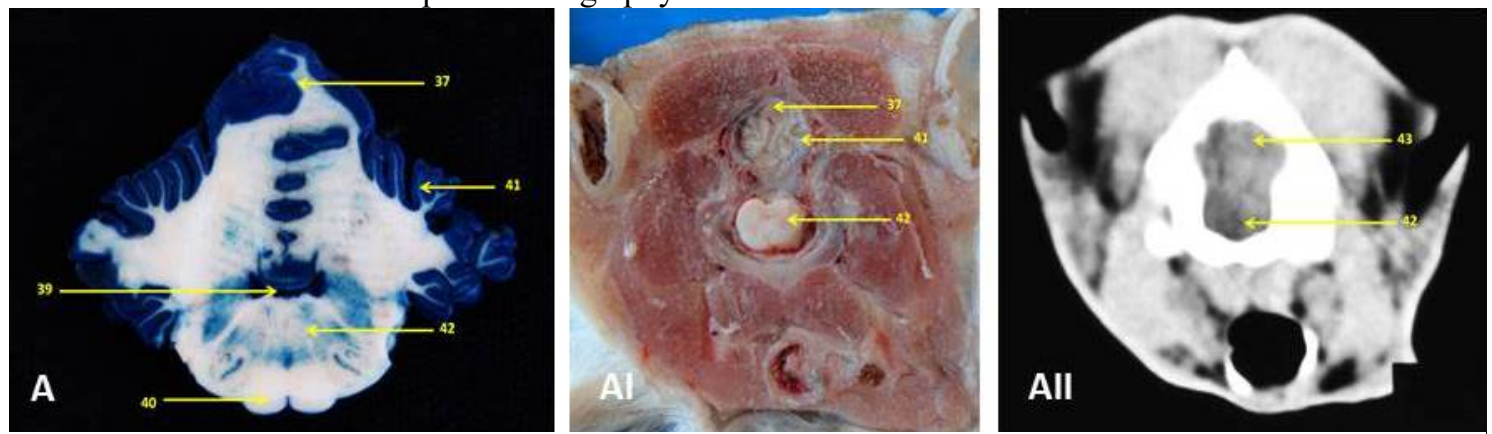

Figure 9. Images corresponding to transverse sections of the cat's brain with identification of anatomical structures. A: Section of brain stained using the Barnard, Robert, and Brown technique. AI: Anatomical section of the head. AII: Computed tomography section.

\section{DISCUSSION}

The brain structures were described in approximate terms by correlating the $\mathrm{CT}$ images and the stained sections of the brain. The staining method used was the Barnard, Robert, and Brown technique in accordance with Meneses et al. (2004), which highlights the gray matter, and was described here for the first time in domestic cats.

The brain structures in the cat were found to be smaller when compared to dogs, as described by Lecouteur et al. (1983).

It was not possible to point out the brain structures in a detailed manner on the CT images; there were few conclusive regions when compared to anatomical sections. The brain CT scan of cats was homogeneous with few variations on shades of gray. According to Jones (2004), the brain parenchyma is formed of soft tissue with subtle differences in density, so adjacent anatomical structures should be used as landmarks, a principle used in this experimental model.

No alterations were seen on the domestic cats' post-contrast tomography images, similar to the results published by Jones (2004), which describes no focal enhancement on the normal brain, with the exception of the pituitary gland. Due to this particularity, the author recommends the use of a domestic animal anatomy atlas for adequate identification of brain structures in small animals. In respect to these facts, the tomographic images of healthy cats obtained and compared to anatomical sections in this study can serve as reference, since most studies found in the literature make use of CT as their guide to discuss the alterations (Lecouteur et al., 1983; Lecouteur, 1999; Thomas, 1999; Kawasaki et al., 2003; Adamo, 2005; Forterre et al., 2006; Goulle et al., 2011; Gutierrez-Quintana et al., 2011). The experimental model can serve to guide the anatomical location and extension of brain alterations found on CT scans of cats (Kraft and Gavin, 1999; Thomas, 1999; Kawasaki et al., 2003; Troxel et al., 2003; Goulle et al., 2011), 
and thus correlate them more precisely with the clinical signs manifested by the patients.

\section{CONCLUSION}

Articles and anatomy atlases describing CT images of normal brain of domestic cats are scarce. This experimental model provides a collection of tomographic images compared to anatomical images of the brain of domestic cats using an informative language for veterinary students and veterinary specialists. The association of gross images and tomography aids in finding the anatomy location of brain lesions more precisely, allows for better understanding of neurological clinical signs, and help predict patient prognosis. Furthermore, it serves as a parameter for writing tomography reports, and allows surgical planning for the species in question.

\section{ACKNOWLEDGEMENTS}

Supported by the Brazilian Federal Agency for the Support and Evaluation of Graduate Education - CAPES.

\section{REFERENCES}

ADAMO, P.F. Intracranial epidural mucocele in a cat. J. Am. Anim. Hosp. Assoc., v.41, p.74-77, 2005.

BERTOLINI, G.; PROKOP, M. Multidetector-row computed tomography: technical basics and preliminary clinical applications in small animals. Vet. J., v.189, p.15-26, 2011.

FIKE, J.R.; CANN, C.E.; TUROWSKI, K. et al. Contrast enhancement of brain tumors and irradiated normal brain: a comparison of iohexol and iothalamate. Neuroradiology, v.28, p.61-64, 1986.

FORTERRE, F.; FRITSCH, G.; KAISER, S. et al. Surgical approach for tentorial meningiomas in cats: a review of six cases. J. Feline Med. Surg., v.8, p.227233, 2006.

GOULlE, F.; MEIGE, F.; DURIEUX, F. et al. Intracranial meningioma causing partial amaurosis in a cat. Vet. Ophthalmol., v.14, p.93-98, 2011.
GUTIERREZ-QUINTANA, R.; GUNN-MOORE, D.A.; LAMM, C.G. et al. Feline intracranial meningioma with skull erosion and tumour extension into an area of skull hyperostosis. J. Feline Med. Surg., v.13, p.296-299, 2011

JONES, J. Neuroimaging. In: VITE, C. (Ed.). Braund's clinical neurology in small animals: localization, diagnosis and treatment. Ithaca: International Veterinary Information Service, 2004.

KAWASAKI, Y.; TSURUTA, T.; SETOGAWA, Y. et al. Hydrocephalus with visual deficits in a cat. J. Vet. Med. Sci., v.65, p.1361-1364, 2003.

KRAFT, S.L.; GAVIN, P.R. Intracranial neoplasia. Clin. Tech. Small Anim. Pract., v.14, p.112-123, 1999.

LECOUTEUR, R.A. Current concepts in the diagnosis and treatment of brain tumours in dogs and cats. $J$. Small Anim. Pract., v.40, p.411-416, 1999.

LECOUTEUR, R.A.; FIKE, J.R.; CANN, C.E. et al. $\mathrm{X}$-ray computed tomography of brain tumors in cats. $J$. Am. Vet. Med. Assoc., v.183, p.301-305, 1983.

MENESES, M.S.; PEDROSO, J.M.; FUZZA, R.F. et al. Análise comparativa de cortes de encéfalos humanos com coloração por três técnicas diferentes. Arq. Neuro-Psiquiatr., v.62, p.276-281, 2004.

OHLERTH, S.; SCHARF, G. Computed tomography in small animals - basic principles and state of the art applications. Vet. J., v.173, p.254-271, 2007.

STICKLE, R.L.; HATHCOCK, J.T. Interpretation of computed tomography images. Vet. Clin. N. Am. Small Anim. Pract., v.23, p.417-435, 1993.

TIDWELL, A.S. Principles of computed tomography and magnetic resonance imaging. In: TRHALL, D.E. (Ed.) Textbook of veterinary diagnostic radiology. 5ed. Philadelphia: W.B. Saunders, 2007. cap. 4, p. 5077

THOMAS, W.B. Nonneoplastic desorders of the brain. Clin. Tech. Small Anim. Pract., v.14, p.125-147, 1999.

TROXEL, M.T.; VITE, C.H.; VAN WINKLE, T.J. et al. Feline intracranial neoplasia: retrospective review of 160 cases (1985-2001). J. Vet. Intern. Med., v.17, p.850-859, 2003. 